NurseLine Journal

Vol. 6 No. 2 November 2021 p-ISSN 2540-7937 e-ISSN 2541-464X

\title{
PEER GROUP PROXIMITY AND SELF-ESTEEM AMONG BULLY ADOLESCENTS IN BULELENG AND JEMBRANA REGENCY
}

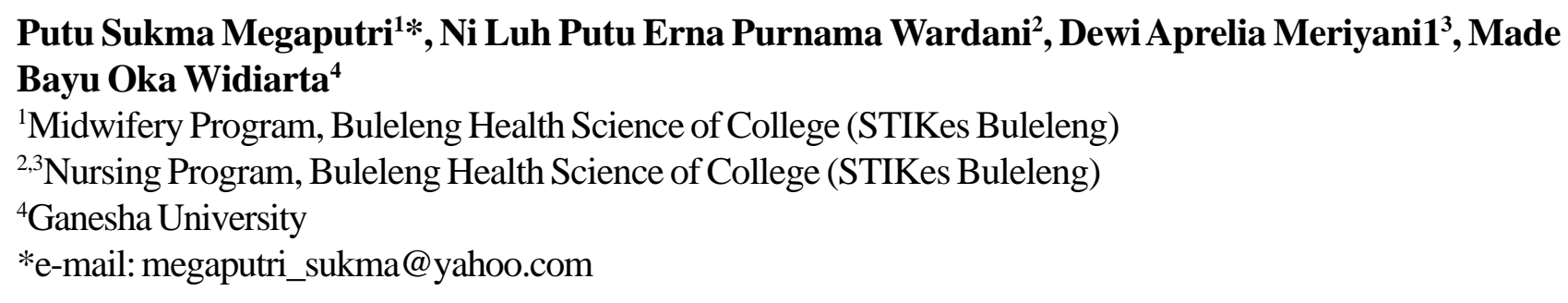

ABSTRACT

Keywords: bully behavior peer group closeness self-esteem
Bullying can be a mental problem for adolescents that has an impact on psychological disorders to suicide, not only for the victim but also for the bully. Handling the impact of bullying so far has only focused on victims, attention should also be directed to bully, because bully is the main actor in the occurrence of bullying. To analyze the relationship between self-esteem and peer group proximity with bully behavior among adolescents in Buleleng and Jembrana. Quantitative research with a cross-sectional approach, samples were taken from junior high school students in Buleleng and Jembrana Districts with 78 respondents and used stratified random sampling for sampling method. The measuring instrument used a questionnaire to screen adolescents who tend to be bully, a self-esteem questionnaire, a peer group closeness questionnaire and a bully behavior questionnaire. The number of samples in this study were 78 people taken by stratified random sampling technique. Univariate analysis was carried out to determine the sociodemographic characteristics of the respondents, then the analysis of the relationship between self-esteem and bully behavior used Rank Spearman as well as the relationship between peer group proximity and bully behavior. Self-esteem has a significant relationship with $\mathrm{p}<0.05, \mathrm{r}=$ 0.867 with teenage bullying. Peer group closeness has a significant relationship with $\mathrm{p}$ $<0.05, r=-0.556$ with bully behavior. Self-esteem and peer group proximity are significantly associated with bullying behavior. The higher the level of self-esteem and peer group closeness, the lower the bullying's behavior.

\section{BACKGROUND}

Bullying is a mental health problem for adolescents that often occurs among adolescents. Bullying gets less attention because it is considered normal. Bullying is an action carried out by an individual or group, which abuses strength or power to other individuals who are weaker physically or mentally (Amini, 2008). Bully is the term for bullying.

WHO data states that $42 \%$ of boys and $37 \%$ of girls in 40 developing countries are involved incases bullying (WHO, 2017). A survey conducted in Minesotta America on 162,034 children of elementary school age (SD) and junior high school (SMP), it was found that $47 \%$ had bullying other students
(Olweus \& Limber, 2010). 40\% of children in Indonesia experience cases of bullying at school. Most of the bully ( bullies) not realizing that they have been or are doing bullying (Hastuti \& Puspitawati, 2015).

Bullying that occurs is like an iceberg phenomenon, only a small number of cases can be revealed (Widiharto, 2011). The perpetrator or victim of bullying will get a negative psychological impact. Students who become bully show a lack of empathy, dominance, are impulsive, and tend to invite others to be hostile (Usman, 2013).

The hope is that if it is focused on bully, by reducing bullying, it will reduce the risk of bullying victims, so that bullying can be avoided. The right intervention certainly requires an assessment of the 
approach to trigger factors of a teenager to behave as a bully.

In adolescence, the existence of friends is a dominant factor affecting him. Peers will form emotional closeness between adolescents so that, if adolescents do not have this bond, they tend to think that other people are not important and will become bully (Yusuf \& Fahrudin, 2012). Apart from external factors, internal factors in adolescents themselves, namely self-esteem, will greatly influence the tendency of adolescents to behave as bully. Based on the results of the study, adolescents with low selfesteem tend to engage in bullying as compensation for their low self-esteem (Mulyati, 2015).

Bully prevalent in schools that have students with differences in students' language used in communicating, skin color, hair color or frequent bullying among students (Tolsma, van Deurzen, Stark, \& Veenstra, 2013).This condition of cultural differences was found in SMP Negeri 1 Mendoyo Jembrana and SMP Negeri 1 Gerokgak Buleleng, whose people have a mixture of Balinese and Javanese cultures. The results of the initial interviews conducted on 15 teenagers at SMP Negeri 1 Gerokgak found that 11 teenagers had committed acts of bullying verbally, physically, and psychologically to friends in the school environment.

The specific purpose of this study was to examine adolescent behavior and the influence of peer closeness. The direction and strength of the relationship are also seen in this study. The urgency of this research is to see that bullying is one of the actions that has a serious impact on both the victim and the behavior. The general objective of this research is to provide data so that bullying behavior can be reduced.

\section{METHODS}

This research is a quantitative study with cross sectional research design. Samples are students who tend to be the bully (bullies) in SMP N 1 Mendoyo in Jembrana District, SMPN 1 Gerokgak Buleleng obtained from the survey conducted by researchers using questionnaires Bullying Behavior Scale.

Sample selected based on stratified random sampling (stratification). This sample location in Gerokgak Junior High School in Buleleng. The student inclusion criteria based on the results were screening more dominant as bully, willing to be a respondent, live in the same house with both biological parents. The exclusion criteria of this study were students who were sick during data collection, students who did not get permission from their parents (deci- sion holders) with evidence of signatures informed consent. The sampling technique was taken based on a sample size formula with multiple proportions obtained a sample size of 78 respondents.

The research instrument used was a selfesteem measurement questionnaire, namely the Rosenberg Self Esteem Scale questionnaire. Consists of 10 statement items (Lipnevich, Preckel, \& Roberts, 2016). Measurement of peer group proximity using a modification of the Inventory of Parents and Peer Attachment-Revised questionnaire. Consists of 12 statement items (Gullone \& Robinson, 2005).Questionnaire Bullying Behavior Scale, consist of 12 items to measure statement Bully behavior in adolescents (CDC, 2011). Furthermore, the screening measurement bully a questionnaire which tested the validity and reliability that is Bullying Behavior

Scale. Consists of 22 statement items (CDC, 2011). The research data collection was carried out by the researcher with the assistance of a research assistant, namely a master nurse specializing in mental health nursing. Before conducting data collection, first conduct a questionnaire trial to see the content first conduct a questionnaire trial to see the content and substantial of the questionnaire, after which the questionnaire is communicated with the research assistant and discussed about the aims and objectives to be achieved from the questionnaire. The data collection is done by selecting the respondents are students who have been approved in the form of Informed Consent from parents to participate in the study. The consent researcher distributed the form study. The consent researcher distributed the form to the students, then the students gave it to their parents and on the next day collected it back to the research team. After the parents agreed that their students / children were involved in the study, the research team then screened all students and rated those who were more dominant as bully with the Bullying Behavior Scale. Furthermore, students who tend to be bully (bullies) are randomly selected by giving each respondent a number and shuffling the number.

Respondents whose numbers came out in the shuffling will enter as research samples at each level (stratification) to reach 58 people, the total sample is 19 people in first grade, 20 people in second grade and 19 people in third grade. The Bully screening questionnaire and the Bully behavior were adopted questionnaire and the Bully behavior were adopted and modified from the questionnaire Bullying Behavior Scale. The peer group proximity questionnaire was modified from the Inventory of Parents and Peer Attachment-Revised. The self-esteem questionnaire 
Table 1. Characteristics of Respondents based on Sociodemographic Data

\begin{tabular}{|c|c|c|}
\hline Characteristics & $\mathbf{f}$ & $\%$ \\
\hline \multicolumn{3}{|l|}{ Age: } \\
\hline 12 & 1 & 1.3 \\
\hline 13 & 26 & 33.3 \\
\hline 14 & 25 & 32.1 \\
\hline 15 & 20 & 25.6 \\
\hline 16 & 6 & 7.7 \\
\hline Total & 78 & 100 \\
\hline \multicolumn{3}{|l|}{ Species Gender: } \\
\hline Male & 50 & 65.4 \\
\hline Female & 27 & 34.6 \\
\hline \multicolumn{3}{|l|}{ Parents' Education Level (Father): } \\
\hline School & 0 & 0 \\
\hline Out of Graduated Primary School & 2 & 2.6 \\
\hline Graduated Junior & 32 & 41 \\
\hline High School & 39 & 50 \\
\hline Graduated Graduate / Diploma & 5 & 6.4 \\
\hline \multicolumn{3}{|l|}{ Occupation of Parents (Father): } \\
\hline PNS / TNI / POLRI (Civil servant) & 4 & 5.1 \\
\hline BUMN / BUMD & 1 & 1.3 \\
\hline Farmers & 49 & 62.8 \\
\hline Private Employees & 23 & 29.5 \\
\hline Not Working & 1 & 1.3 \\
\hline \multicolumn{3}{|l|}{ Parents' Income: } \\
\hline $500000-1000000$ & 20 & 25.6 \\
\hline$>1000000-2000000$ & 52 & 66.7 \\
\hline$>2000000$ & 6 & 7.7 \\
\hline Distance Home to School & 2( & \\
\hline \multicolumn{3}{|l|}{ Transportation to school: } \\
\hline Squire by the Parent & 54 & 20.5 \\
\hline Up Public Transport & 8 & 10.3 \\
\hline Walking / Bike Ride & 16 & 69.2 \\
\hline \multicolumn{3}{|c|}{ Media Information Most Frequently Accessed: } \\
\hline Internet & 4 & 5.1 \\
\hline TV / Radio & 7 & 9 \\
\hline Social Media & 67 & 85.1 \\
\hline \multicolumn{3}{|c|}{ Experience being a Victim of Bullying: } \\
\hline Yes & 51 & 64.1 \\
\hline Not Yet & 27 & 35.9 \\
\hline
\end{tabular}

was modified from the Rosenberg Questionnaire Self Esteem Scale. All questionnaires have been tested for validity and reliability on 20 respondents with characteristics that are almost the same as the research respondents with the corrected item-total items correlation value $>0.3$ and Cronbach's Alpha 0.852 so that it can be concluded that the questionnaire is valid and reliable.

Univariate analysis conducted to determine the proportion and distribution of each variable. Bivariate analysis was conducted to see the relationship and direction of the relationship between the independent variables and the dependent variable. The test used is Rank Spearman. The significance is seen from the $\mathrm{p}$ value $<0.05$. Testing the relationship between all independent variables and the dependent variable is to find the variable that related to bullying teenage. 
Table 2. Characteristics of respondents based on Bully Behavior, Self-Esteem, and Peer Group Closeness

\begin{tabular}{lll}
\hline Variable & f & \% \\
\hline Self-esteem: & 2 & 2.6 \\
High Self-esteem & 76 & 97.4 \\
Low Self-esteem & & \\
\hline The proximity of the peer group: & 1 & 1.3 \\
Very close & 8 & 10.3 \\
Pretty close & 69 & 88.5 \\
Less close & & \\
\hline Behavior Bully: & 66 & 84.6 \\
Behavior Bully high & 12 & 15.4 \\
Behavior Bully moderate & 0 & 0 \\
Bully behavior is low & & \\
\hline
\end{tabular}

Table 3. Table of Bivariate Analysis of Self-Esteem Variables, Peer Group Closeness With Bully

\begin{tabular}{lll}
\hline \multirow{2}{*}{ Variables } & \multicolumn{2}{c}{ Bully Behavior } \\
\cline { 2 - 3 } & $\mathbf{r}$ & $\mathbf{p}$ \\
\hline Self-esteem & -0.867 & 0.001 \\
\hline Peer group proximity & -0.556 & 0.001 \\
\hline
\end{tabular}

\section{RESULTS}

In this study the data on the sociodemographic characteristics of respondents were data on age, gender, education level of parents (father), parent's occupation (father), parents' income, distance from home to school, transportation to school, information media Most frequently accessed, experiences of being victims of bullying student are shown in the following table:

Based on the results of data analysis in table 1 , the results of the characteristics of respondents based on sociodemographic data indicate that most of the respondents are 26 people (33.3\%) are 13 years old. The majority of respondents, namely 50 people $(65.4 \%)$ were male. At the education level, the majority of parents (fathers), namely 39 (50\%) graduated from high school, with the majority of parents' jobs, namely farmers, as many as 49 people (62.8\%). Furthermore, the majority of parents' income was found, namely 52 people (66.7\%) earning 1 million rupiah to 2 million rupiah per month. The distance between students from home to school is 1 to 15 kilometers. In the information media most frequently accessed, 67 people (85.1\%) accessed social media the most (Facebook, Instagram, WhatsApp, Twitter etc.). Most of it, namely 51 people (64.1\%) had been victims of bullying.

Table 2 shows that the majority of adolescent self-esteem levels are low, namely 76 people (97.4\%). Furthermore, the closeness of the peer group showed that most of them, namely 69 people (88.5\%), had less peer group proximity. On bully behavior, it can be seen that most of the 66 people (84.6\%) teenage students have bully behavior in the high category.

It can be seen that self-esteem has a significant relationship with bully behavior with a significance value of $p 0.001<0.05$ with a value of $r=$ 0.867 , which means that there is a significant relationship between self-esteem and bully behavior. The negative sign shows that there is an opposite relationship between self-esteem and bullying behavior. The higher the self-esteem, the lower the student's bullying behavior and vice versa. The second variable also shows that there is a significant relationship between peer group closeness and bullying in adolescents with a significance value of p $0.001<0.05$ with a value of $r=-0.556$ which means that there is a significant relationship between peer group closeness and bullying behavior. The negative sign shows that there is an opposite relationship between peer group proximity and bullying behavior. The higher the level of peer group proximity, the lower the level of bullying in adolescents.

\section{DISCUSSION}

Bullying is a form of behavior that often occurs among teenagers and has not received special attention from related parties. This bullying behavior varies greatly in each group of adolescents, both physical, verbal and psychological bullying. This is 
related to the characteristics of adolescents who commit bullying or what is called Bully (bullying).

In the research results, it can be seen that the sociodemographic characteristics of the age of most bully are adolescents, namely 13 years. In a study, from 665 adolescents who participated as respondents, it was found that the average teenager who was involved in bullying was in the age range of 13 years (Khamis, 2015). In this adolescence, the development cycle that is happening is a high ego centric, so that there is a desire to look dominant compared to other people, which if there is a misperception of the adolescent, the direction is to commit or be involved in bullying.

Boys are more often involved in acts of bullying, namely as bully (perpetrators). This is also supported by the research of Herman, Nurshal, and Oktarina (2018) which found that there was a significant relationship between gender and bullying. In this study states that there are significant differences between men and women in bullying behavior. Male gender tends to be bully compared to female, especially physical and verbal bullying, while female students are more likely not to be directly involved as perpetrators but as supporters of the actions taken by a bully. Male students in their social group tend to be bullies, because they want to show their masculine side in the social environment.

The results showed that most of the students who tended to be bullies were in the middle to low family economic level as evidenced by the fact that most parents worked as farmers with an average income of 1 million to 2 million per month. This is supported by research by (Copeland, Wolke, Angold, \& Costello, 2013) which found that bullying is the most common act of children with family economic levels. This is related to the level of depression in the family which is channeled into bullying behavior between children or adolescents. This result is also supported by the research of (Herman et al., 2018) who found that most adolescents with moderate to low economic levels tend to be directly involved in bullying. According to some experts, the tendency of students to be bullies is due to family factors. The condition of a family who lives in an adequate to insufficient economic condition has the risk of distress in the family. Distress conditions will lead to conditions that are less harmonious, inadequate, the parenting system is more towards verbal and physical violence. Such parenting is identical to the psychological effect of a child following and imitating this behavior to other people or peers (Zakiyah, Humaedi, \& Santoso, 2017).

In addition, other characteristics that are quite prominent in bully adolescents, namely the results show that most of the respondents, namely 51 people (64.1\%), indicate that they have been victims of bullying as well. These results are in line with the research results of Zakiyah et al. (2017) who found that the type of bullying perpetrator or what is called bully is anxious and at a certain time the bully has become a victim of bullying as well. Another study also found that out of 236 students found that the majority, namely 104 (44.1\%) students stated that they were not only perpetrators but had also been victims (Sterzing et al., 2020). This happens, because the experience has been a victim of bullying, this victim will commit the wrong coping mechanism, namely by taking revenge so that he becomes bully as well.

Social media is the media most frequently accessed by students, namely 67 people (85.1\%) compared to other information media. Nowadays, with the advancement of traditional bullying technology, it has developed into cyberbullying, namely bullying that is carried out in cyberspace with the facilitation of internet media and telecommunications devices such as cellphones. In his research Nilan, Burgess, Hobbs, Threadgold, and Alexander (2015) Found that students who bully in cyberspace are students who are active in the use of social media on smartphone devices. The characteristics of social media are the ability and sophistication in combining voice, video and text media in real time or in a short time at that time, so this is where the ability of social media is misused by teenagers to become bullying media (Hidajat, Adam, Danaparamita, \& Suhendrik, 2015). Social media without a good filtering system is very vulnerable and is filled with content that directs students or teenagers to engage in bullying.

Most of the bullies in this study had low selfesteem. In accordance with the research conducted by Yusuf and Fahrudin (2012), where most bullies or bullies tend to have low self-esteem so that they commit bullying. Likewise the closeness of peer groups. The high proportion of peer closeness of bullied adolescents is in the range of lack of closeness. This can be seen also in the research of Yusuf \& Fahrudin (2012) which states that adolescents with a distant level of peer group closeness mostly behave as bully because they feel neglected by the group so that channel the dissatisfaction by behaving as bully.

Bivariate analysis showed that there was a significant relationship between self-esteem and bullying behavior with the opposite direction of the relationship. The higher the adolescent self-esteem, the lower the tendency to behave as bully and vice versa, the lower the adolescent self-esteem, the tendency 
to increase bully behavior. Self-esteem is a reflection of the recognition or appreciation of an individual for his achievements and current conditions. Adolescents with high self-esteem have an attitude of respect, recognition, appreciation for what conditions exist in them at this time so that they will feel love and love for themselves. This love will be implemented not only for oneself but also for others so that the tendency to commit actions that hurt, offend others will be less likely.

The results of this study are also supported by research conducted by Sandri (2015) which states that there is a significant relationship between selfesteem and adolescent bullying behavior. In this study, it is stated that the condition of low self-esteem can be understood that when an individual considers himself worthless, in the end, he does not love himself too much, so that the compensation for this condition becomes a bully to get recognition from the victim, resulting in a satisfaction.

This study is in line with the research of Fanti and Henrich (2015) who found in their research the opposite relationship between self-esteem and bullying behavior. Low self-esteem has a strong relationship with the tendency to be a bully. Student selfesteem tends to be lower in students who are involved as victims of bullying, bullying and victims and perpetrators at once compared to students who are not involved as victims, as perpetrators or perpetrators and victims at the same time (Hesapçiolu, Meraler, \& Ercan, 2018).

This peer group factor greatly influences each student to tend to bullying behavior. This is because the encouragement of recognition and efforts to be included in certain groups in the association so that these students try to bully so that they can be included in that group, even though the students themselves are not comfortable doing it. After entering the group, these students will continue to be forced to take bullying, which has become the habit and belief of the group of students to appear dominant (Zakiyah et al., 2017). The proximity of peer groups and the closeness that is built in the family environment is related to the small number of possible bullying occurring and to increase the role of students in defending the conditions of victims of bullying not to experience physical, verbal or social violence if there is a situation of bullying (Murphy, Laible, \& Augustine, 2017).

Adolescents with a low level of peer group proximity, when facing a distress condition, often experience a loss of support (support system) from members in the group. Bully behavior often occurs in early adolescence, where in this period adolescents need a close relationship with their friends as a social support for themselves. The proximity of peer groups during adolescence has a very crucial role (Zhao \& Chang, 2019).

The limitation of this study is the researchers must adapt to corona condition of this study is that researchers have to complete this research in conditions of the corona 19 pandemic, this limits researchers from conducting field studies and face-toface interviews with bully victims in junior high school and teenagers in junior high school in Buleleng.

\section{CONCLUSION}

Bully behavior occurs a lot in adolescents in the school environment and until now it has not received much attention because it is considered normal, while on the other hand the impact of this behavior will be dangerous for psychological development in adulthood, both the bullying itself. nor the victim. The results of the characteristics of the respondents in this study showed that most of the bullies were male with middle to lower socioeconomic conditions and most of the parents' jobs were farmers. Social media is the information media most accessed by bullies. The majority of the bully students' selfesteem in this study was low as well as the closeness of the peer group that was in the low category. The majority of teenage bully behavior is in the high bully behavior category. The results of the data analysis found that there was a significant relationship with the direction of the opposite relationship between selfesteem and peer group closeness with bully behavior of adolescents.

\section{ACKNOWLEDGMENTS}

The authors say thank you to the Directorate of Research and Community Service for the financial support provided and the opportunity to participate in research grants. We also thanks to the Headmaster of junior high school in Mendoyo and Gerokgak.

\section{REFERENCES}

Amini. 2008. Bullying: mengatasi kekerasan di sekolah dan lingkungan sekitar anak, Jakarta: PT. Grasindo.

CDC. 2011. Measuring Bullying, Victimization, Perpetration, and Bystander, Experiences: A Compendium of Assessment Tools. Giorgia 
National Center for Injury Prevention and Control.

Copeland., William, E. 2013. Adult Psychiatric Outcomes Of Bullying And Being Bullied By Peers In Childhood And Adolescence. JAMA psychiatry, 70(4), 419-426.

Fanti., Kostas, A., and Henrich, C. 2015. Effects Of Self-Esteem And Narcissism On Bullying And Victimization During Early Adolescence. The Journal of Early Adolescence, 35(1), 5-29.

Gullone, Eleonora, \& Robinson, Kym. 2005. The Inventory Of Parent And Peer AttachmentRevised (IPPA?R) For Children: A Psychometric Investigation. Clinical Psychology \& Psychotherapy, 12(1), 67-79.

Hastuti., Dwi., \& Puspitawati, H. 2015. Gaya Pengasuhan Ibu Dan Perilaku Bullying Remaja Pada Keluarga Bercerai Di Kota Bogor. Bogor Agricultural University (IPB).

Herman., Hermalinda., Nurshal., Deswita., \& Oktarina, E. 2018. Hubungan Karakteristik Remaja Dengan Perilaku Bullying Pada Siswa SMP Di Kota Padang. Jurnal Keperawatan Soedirman, 12(1), 1-11.

Hesapçio?lu., Selma, T., Meraler., Habibe, Y., \& Ercan, F. 2018. Bullying In Schools And Its Relation With Depressive Symptoms, SelfEsteem, And Suicidal Ideation In Adolescents. Anadolu Psikiyatri Dergisi, 19(2), 210216.

Hidajat., Monica., and Suhendrik. 2015. Dampak Media Sosial dalam Cyber Bullying. ComTech: Computer, Mathematics and Engineering Applications, 6(1), 72-81.

Khamis., Vivian. 2015. Bullying Among School-Age Children In The Greater Beirut Area: Risk And Protective Factors. Child abuse \& neglect, 39, 137-146.

Lipnevich, A., Preckel, F., \& Roberts, R.D. 2016. Psychosocial Skills and School Systems in the 21st Century: Theory, Research, and Practice: Springer International Publishing.

Mulyati. 2015. Hubungan Tingkat Harga Diri Dengan Perilaku Bullying Pada Anak Usia Sekolah Kelas Iv Dan V Di SD Negeri Bumijo Yogyakarta. STIKES'Aisyiyah Yogyakarta.

Murphy., Tia, P., Laible., Deborah., \& Augustine, M. 2017. The Influences Of Parent And Peer Attachment On Bullying. Journal of child and family studies, 26(5), 1388-1397.

Nilan., Pam., Burgess., Haley., Hobbs., \& Alexander, W. 2015. Youth, Social Media, And
Cyberbullying Among Australian Youth:"Sick Friends". Social Media+ Society, 1(2), 2056305115604848.

Olweus., Dan., \& Limber., Susan . 2010. Bullying In School: Evaluation And Dissemination Of The Olweus Bullying Prevention Program. American Journal of Orthopsychiatry, 80(1), 124-134.

Sandri., Ritna. 2015. Perilaku Bullying Pada Remaja Panti Asuhan Ditinjau Dari Kelekatan Dengan Teman Sebaya Dan Harga Diri. Jurnal Psikologi Tabularasa, 10(1).

Sterzing., Paul., Auslander., Wendy., \& Jonson-Reid, M. 2020. Exploring Bullying Perpetration And Victimization Among Adolescent Girls In The Child Welfare System: Bully-Only, VictimOnly, Bully-Victim, And Noninvolved Roles. Journal of interpersonal violence, 35(5-6), 1311-1333.

Tolsma., Jochem., \& Veenstra, R 2013. Who Is Bullying Whom In Ethnically Diverse Primary Schools? Exploring Links Between Bullying, Ethnicity, And Ethnic Diversity In Dutch Primary Schools. Social Networks, 35(1), 5161. doi: https://doi.org/10.1016/ j.socnet.2012.12.002

Usman., Irvan. 2013. Kepribadian, Komunikasi, Kelompok Teman Sebaya, Iklim Sekolah Dan Perilaku Bullying. HUMANITAS (Jurnal Psikologi Indonesia), 10(1), 49-60.

WHO. 2017. Global Strategy For Women's, Children's And Adolescents' Health (2016-2030). Organization, 2016(9).

Widiharto, A. 2011. Perilaku Bullying, Harga Diri Dan Pemahaman Moral Anak. Metamorfosis, 5(19).

Yusuf., Fahrudin, A. 2012. Perilaku bullying: asesmen multidimensi dan intervensi sosial. Jurnal Psikologi Undip, 11(2), 10.

Zakiyah., Ela, Z., Humaedi., Sahadi., \& Santoso. 2017. Faktor Yang Mempengaruhi Remaja Dalam Melakukan Bullying. Prosiding Penelitian dan Pengabdian kepada Masyarakat, 4(2).

Zhao., Ruo, B., \& Chang., Yuan. 2019. Students' Family Support, Peer Relationships, and Learning Motivation and Teachers Fairness Have an Influence on the Victims of Bullying in Middle School of Hong Kong. International Journal of Educational Methodology, 5(1), 97-107. 